\title{
Depolarization Maintains Neurites and Priming of PC12 Cells after Nerve Growth Factor Withdrawal
}

\author{
Kenneth K. Teng and Lloyd A. Greene \\ Department of Pathology and Center for Neurobiology and Behavior, Columbia University, College of Physicians and \\ Surgeons, New York, New York 10032
}

In contrast to its actions on certain neural populations, membrane depolarization by elevated $\mathrm{K}^{+}$promotes neither the survival nor the differentiation of PC12 cells. We therefore employed this model system to examine directly the actions of elevated $\mathrm{K}^{+}$on neurites. Here we report that elevated $\mathrm{K}^{+}$ prevents the degeneration of neurites that occurs when NGF is withdrawn from PC12 cell cultures. This effect is inhibited by the L-type $\mathrm{Ca}^{2+}$ channel blockers verapamil and nitrendipine. Although depolarization preserves preexisting neurites, unlike NGF, it does not promote neurite elongation. In addition to neurite stabilization, elevated $\mathrm{K}^{+}$also maintains NGF-deprived cells in a "primed" state in which they can rapidly regenerate neurites when re-treated with NGF. Elevated $\mathrm{K}^{+}$alone has no priming effect, nor is it neuritogenic on either naive or NGF-pretreated cells. To probe the molecular basis for these actions of depolarization, we examined several cytoskeletal proteins whose phosphorylations ( $\beta$-tubulin, MAP 1.2/1B, and 64, 72 and $80 \mathrm{kDa}$ chartins) or levels (MAP 1.2/1B and peripherin) are regulated by NGF in parallel with neurite outgrowth. Elevated $K^{+}$alone does not mimic these effects of NGF. In all cases, NGF withdrawal leads to the return of these proteins to levels characteristic of naive cells; in contrast, with the exception of the $80 \mathrm{kDa}$ chartins, depolarization of NGF-deprived cultures maintained these proteins at or near their NGF-stimulated states. Similar observations were obtained with the NILE/L1 glycoprotein. These findings suggest that elevated $K^{+}$preserves priming and preexisting neurites by maintaining NGF-induced changes in cell composition. Our experiments invoke the possibility that elevation of intraneuronal $\mathrm{Ca}^{2+}$ may lead to selective stabilization of preexisting axons or dendrites in the intact nervous system, especially under circumstances in which the supply of neurotrophic factors is absent or limiting.

[Key words: calcium channel, cytoskeleton, elevated potassium, neurite outgrowth, neuronal differentiation, PC12C41 cells]

\footnotetext{
Received Oct. 20, 1992; revised Jan. 8, 1993; accepted Feb. 8, 1993.

We thank Drs. Richard Vallee and Wilfredo Mellado for generous gifts of antiserum 1B-4 and bovine MAPs, respectively. We also acknowledge Kristy Brown for her skillful assistance with electron microscopy. This work was supported by grants from NIH-NINDS.

Correspondence should be addressed to Kenneth $\mathrm{K}$. Teng, Department of Pathology, Columbia University, College of Physicians and Surgeons, 630 West 168th Street, New York, NY 10032.

Copyright (C) 1993 Society for Neuroscience $0270-6474 / 93 / 133124-12 \$ 05.00 / 0$
}

The outgrowth of neurites from immature nerve cells in response to differentiating signals is one of the hallmark events of nervous system development. Neuritogenesis is a complex process that requires concerted interaction among various cytoskeletal elements, as well as the involvement of other proteins whose behaviors are also modulated during neuronal differentiation (for review, sec Aletta ct al., 1990; Levi and Alemá, 1991). Moreover, there appear to be distinct phases of outgrowth including initiation, advancement, consolidation, and stabilization of neurites (Goldberg and Burmeister, 1986; Aletta and Greene, 1988). To understand the mechanism of neurite formation and maintenance, it would therefore be advantageous to develop means to dissect these stages from one another experimentally. It would also be important to determine whether neurons may encounter conditions that will differentially influence only a subset of these phases of neurite behavior.

The rat pheochromocytoma PC1 2 cell line (Greene and Tischler, 1976) has been a valuable model for studying the neurotrophic and differentiating effects of NGF (for review, see LeviMontalcini and Angeletti, 1968; Levi and Alemá, 1991). Exposure of PC1 2 cells to NGF results in their conversion from immature adrenosympathetic precursor-like cells to cells that resemble mature sympathetic ncurons (Grcene and Tischler, 1982). In particular, NGF-treated PC1 2 cells develop long, branching neurites. Experiments with PC12 cells have revealed that neurite outgrowth requires both transcription-dependent and -independent actions of NGF (Burstein and Greene, 1978). Synthesis-dependent actions associated with neurite outgrowth include enhanced levels of specific microtubule-associated proteins (MAPs; Greene et al., 1983; Lewis et al., 1986; Aletta et al., 1990) and of certain cell surface glycoproteins (Salton et al., 1983; Prentice et al., 1987). Examples of nonsynthetic effects of NGF that correlate with neurite outgrowth include enhanced phosphorylation of particular MAPs (Aletta and Greene, 1987; Aletta et al., 1988b) and of $\beta$-tubulin (Black et al., 1986; Aletta and Greene, 1987) as well as of molecules that may play roles in adhesion (Halegoua, 1987).

Cellular treatments that mimic elements of the actions of NGF have the potential to permit dissection of the mechanisms underlying neurite outgrowth. One such treatment is exposure to depolarizing levels of extracellular $\mathrm{K}^{+}$. Elevated $\mathrm{K}^{+}$has been reported to promote survival of cultured sympathetic neurons after withdrawal of NGF (Wakade et al., 1988; Koike et al., 1989). Under such conditions, the $\mathrm{K}^{+}$-treated cells also appear to retain their neurites. This raises the issue as to whether elevated $\mathrm{K}$ ' has direct actions on neurite maintenance, or whether this effect is an indirect consequence of the ability of depolar- 
ization to promote survival. Recent findings that promotion of ncuronal survival by NGF and other agents can be experimentally distinguished from the capacity to elicit neurite outgrowth (Greene et al., 1990; Batistatou and Greene, 1991; Rukenstein et al., 1991) raise the possibility of direct neurite-stabilizing actions of elevated $\mathrm{K}^{+}$

Because elevated $\mathrm{K}^{+}$has neither survival-promoting nor neuritogenic actions on PC1 2 cells (Greene et al., 1982; Rukenstein et al., 1991), this cell line is highly suitable for examining possible direct effects of membrane depolarization on neurites. We show here that elevated $\mathrm{K}^{+}$maintains both priming and neurite stability in PC1 2 cell cultures after withdrawal of NGF. This phenomenon has permitted us to begin to dissect the mechanisms underlying neurite outgrowth. It also suggests the possibility that membrane depolarization may have a role in neurite maintenance in the nervous system.

A portion of this work has previously been presented in abstract form (Teng and Greene, 1991).

\section{Materials and Methods}

Reagents. NGF was prepared from adult mouse submaxillary glands as previously described (Mobley et al., 1976) and was used at a concentration of $50 \mathrm{ng} / \mathrm{ml}$. Verapamil was obtained from Sigma Chemical Co., St. Louis, MO. Nitrendipine was from Miles Pharmaceuticals, West Haven, CT. Monoclonal antiserum 1B-4 raised against purified bovine MAP 1B (Bloom et al., 1985) was kindly provided by Dr. Richard Vallee (Worcester Foundation for Experimental Biology, Worcester, MA). All radiolabeling reagents were obtained from Du Pont-New England Nuclear, Boston, MA. Reagents used for electrophoresis were from either Sigma Chemical or Boehringer Mannheim Biochemicals, Indianapolis, IN. Concentrated stocks of running buffers for SDS-PAGE and transfer buffers for electroblotting were purchased from National Diagnostics, Manville, NJ. Protein concentrations were assayed by the method of Bradford (1976) and were carried out with reagents purchased from BioRad Laboratories, Richmond, CA, using bovine serum albumin (BSA) as the standard.

Cell culture. $\mathrm{PC} 12$ and $\mathrm{PC} 12-\mathrm{C} 41$ cells were cultured as previously described (Greene and Tischler, 1976; Greene et al., 1991) on collagencoated dishes in RPMI 1640 medium supplemented with $10 \%$ heatinactivated horse serum and 5\% fetal bovine serum. The PC12-C41 cell line is a clonal variant of the PC12 cell line that extends neurites in greater abundance than their parental cell counterparts. The characterization of this line will be detailed elsewhere (K. K. Teng, J. Nunez, and L. A. Greene, unpublished observations).

Cultures for NGF treatment were seeded at low densities $\left(5 \times 10^{5}\right.$ cells per $35 \mathrm{~mm}$ dish or $1-2 \times 10^{6}$ cells per $100 \mathrm{~mm}$ dish) in RPMI 1640 medium containing $1 \%$ horse serum and $50 \mathrm{ng} / \mathrm{ml} \mathrm{NGF}$ (Greene et al., 1987). Once these cultures had elaborated a robust network of neurites ( $10 \mathrm{~d}$ to 2 weeks, unless otherwise stated), the attached cells were rinsed three times with RPMI 1640 medium plus 1\% horse serum. The cultures were then refed with RPMI 1640 medium plus $1 \%$ horse serum with or without various additives. Where applicable, isoosmotic media with various concentrations of elevated $\mathrm{K}^{+}$were prepared by mixing a $160 \mathrm{mM} \mathrm{KCl}$ stock with appropriate volumes of RPMI 1640 medium plus $1 \%$ horse serum.

Neurite regencration was carricd out and scored as previously described (Burstein and Greene, 1978).

Measurements of neurite outgrowth. Neurite-bearing cells were scored at high magnification $(320 \times)$ as previously described (Burstein and Greene, 1978). Only processes greater than two cell body diameters in length (i.e., about $20 \mu \mathrm{m}$ ) were considered neurites, and cells in the center of clumps that could not be adequately discerned were excluded. For each culture condition, at least 100 cells from randomly choosen fields were scored.

Neurite lengths were determined by the use of an eyepiece equipped with a calibrated micrometer. At least 20 random neurites were measured per culture condition.

Electron microscopy. Cultures of PC12-C4l cells were treated as described (see Results), and were then fixed with $2.5 \%$ glutaraldehyde (Electron Microscopy Scicnces, Ft. Washington, PA) in PBS for $30 \mathrm{~min}$, fixed with $1 \%$ osmium tetroxide (Electron Microscopy Sciences) for 20 min, dehydrated through alcohols, and infiltrated with Epon 812 (SPI Supplies, West Chester, PA) overnight. The cultures were embedded in Epon, processed, and stained with uranyl acetate and lead citrate as previously described (Troy et al., 1992). Examination of thin sections $(60-90 \mathrm{~nm}$ ) was carried with a JEOL $100 \mathrm{~S}$ electron microscope (JEOL USA, Crawford, NJ).

Radiolabeling. Metabolic radiolabeling of PC12-C41 cell cultures in $35 \mathrm{~mm}$ dishes was performed as previously described either in $1 \mathrm{ml}$ of modified Krebs-Ringer, HEPES-buffered solution for $2 \mathrm{hr}$ with 50-300 $\mu \mathrm{Ci} / \mathrm{ml}^{32} \mathrm{P}$-orthophosphate (Black et al., 1986) or in $1 \mathrm{ml}$ of appropriate culture medium with $50 \mu \mathrm{Ci} / \mathrm{ml} \mathrm{L}-\left[5,6,{ }^{3} \mathrm{H}\right]$ fucose for $3 \mathrm{~d}$ (RichterLandsberg et al., 1985). Where applicable, the labeling media contained NGF or 44 mм K+.

Sample preparation and analysis. Whole-cell lysates were prepared as described (Aletta and Greene, 1987) in SDS sample buffer (Laemmli, 1970) and placed immediately in a boiling water bath for $10 \mathrm{~min}$ before analysis by SDS-PAGE.

Preparations enriched in microtubule (MT) and MAPs were generated from cells attached to $35 \mathrm{~mm}$ culture dishes as described (Aletta and Greene, 1987) with the following modifications: Triton/glycerol (MTstabilized) and calcium (MT-enriched) extraction buffers were used at final volumes of $500 \mu \mathrm{l}$. During the extraction procedure, the dishes were gently tilted back and forth in order to extract all the proteins efficiently in a small volume. The extractions were terminated by adding the extracted material to $167 \mu \mathrm{l}$ of $4 \times$ SDS sample buffer and boiling immediately for $10 \mathrm{~min}$.

Discontinuous slab gel electrophoresis (SDS-PAGE) was carried out on $5-10 \%$ gradients of polyacrylamide. Purified bovine MAPs (kindly provided by Dr. Wilfredo Mellado, Columbia University, New York, NY) were included with molecular mass standards (Bio-Rad Iaboratories) to indicate the positions of tubulins and MAP 1B/1.2. The gels containing ${ }^{32} \mathrm{P}$-labeled proteins were fixed, stained, dried, and then exposed to Kodak XAR-5 x-ray film. Gels containing ${ }^{3} \mathrm{H}$-labeled proteins were immersed in $1 \mathrm{M}$ sodium salicylate as described (Chamberlain, 1979) before drying. The dried gels were exposed to XAR-5 $x$-ray film at $-70^{\circ} \mathrm{C}$ with Cronex Lightning Plus enhancing screens.

Western immunoblot analysis. Proteins separated by SDS-PAGE were electroblotted ( $50 \mathrm{~mA}$, overnight) onto supported nitrocellulose ( $\mathrm{S} \& \mathrm{~S}$, Keene, NH) as described by Towbin et al. (1979). Transferred proteins were visualized by staining the membrane with $2 \%$ Ponceau $S$ in $2 \%$ trichloroacetic acid (TCA) and then destaining in distilled water. Blots were blocked with 5\% nonfat milk in PBS for at least $2 \mathrm{hr}$ before further processing.

Monoclonal antibodies against bovine MAP 1B (1B-4; Bloom et al., $1985)$ were used at 1:2000 dilution in PBS containing 1\% BSA and incubation was for at least $2 \mathrm{hr}$. For MAP 1B/1.2 detection, blots were developed with $350 \mathrm{nCi}$ of ${ }^{125} \mathrm{I}$-goat anti-mousc IgG (Du Pont-New England Nuclear)/ml of PBS containing 1\% BSA and were washed five times in PBS. Peripherin protein was detected with a rabbit polyclonal antiserum $(1: 2000$ dilution in $1 \% \mathrm{BSA} / \mathrm{PBS})$ prepared against a synthetic peptide corresponding to the C-terminal portion of the protein (Aletta et al., 1988a). The blots were developed for 60-90 min with ${ }^{125}$ I-Protein A (Du Pont-New England Nuclear) at a final concentration of $350 \mathrm{nCi}$ / $\mathrm{ml}$ of PBS containing 5\% BSA, followed by three washes (20 min each) in $0.05 \%$ Triton X-100/PBS. After the washing steps, blots were exposed to XAR-5 $\mathrm{x}$-ray film at $-70^{\circ} \mathrm{C}$ with an enhancing screen.

Scanning densitometry and statistical analysis. Densitometric scanning of autoradiograms was performed on an Apple OneScanner with ofoto scanning software (Apple Computer Inc., Cupertino, CA). The images were quantified by NIH IMAGE program 1.43 (National Institutes of Health, Bethesda, MD), and the optical density of each band was expressed as total numbers of pixels in the area covered by that band. For quantitation of experiments such as that shown in Figure $7 \mathrm{~A}$, an invariant band $(\approx 85 \mathrm{kDa})$ in each lane was employed to adjust for the loading difference among samples. Where applicable, statistical analyses were performed using Student's $t$ test for two-tailed hypotheses. The difference between two means was considered significant if $p \leq 0.05$.

\section{Results}

Elevated $K^{+}$maintains neurites after $N G F$ withdrawal

PC1 2 clone 41 (PC12-C41) is a clonal variant of the rat pheochromocytoma $\mathrm{PC} 12$ cell line that exhibits greater neuritogenic potential than its wild-type PC. 12 cell counterpart. It was therefore employed along with PC12 cells as a convenient system for 

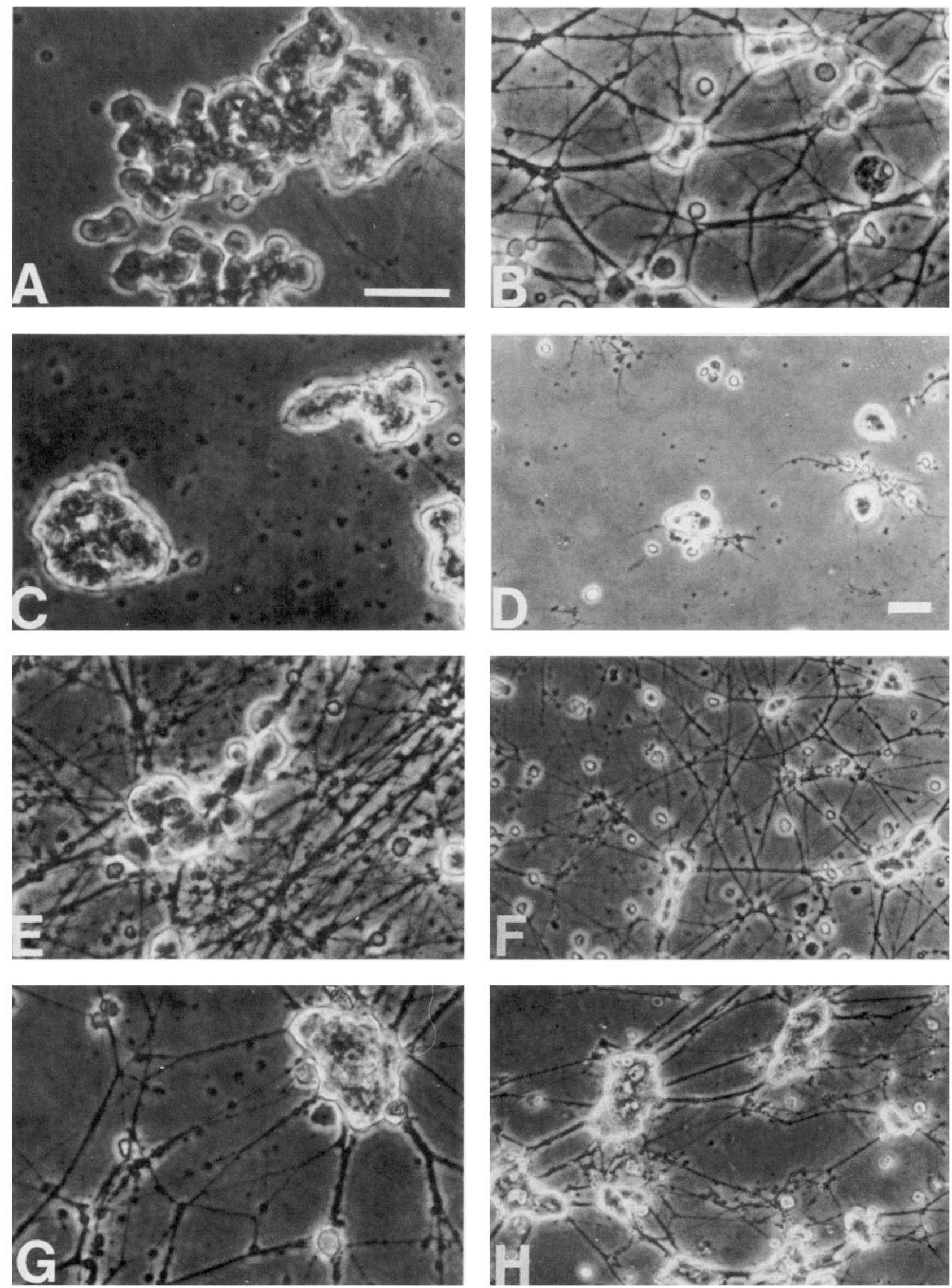

Figure 1. Morphologies of PC12-C41 cell cultures maintained by elevated $\mathrm{K}^{+}$: phase-contrast micrographs of replicate cultures of naive PC12C41 cells $(A)$ or PC12-C41 cells treated with NGF for $12 \mathrm{~d}(B)$ and subsequently switched for $15 \mathrm{~d}$ to either no additives $(C)$, NGF $(E)$, or 44 mM $\mathrm{KCl}(G)$. Also shown at lower magnification are replicate PC12-C41 cell cultures treated for $15 \mathrm{~d}$ with NGF, followed by an additional $14 \mathrm{~d}$ of treatment with no additive $(D), \operatorname{NGF}(F)$, or $44 \mathrm{~mm} \mathrm{~K}^{+}(H)$. Scale bars: $A, 50 \mu \mathrm{m}$ for $A-C$, $E$, and $G ; D, 50 \mu \mathrm{m}$ for $D, F$, and $H$. 
providing a dense neurite network for the purposes of the present study. The following experimental paradigm was designed to assess long-term effects of membrane depolarization on neurite outgrowth and stability. Cells were first exposed to NGF for 12$15 \mathrm{~d}$ to induce formation of a dense neurite network. Replicate cultures were then washed with NGF-free culture medium and subsequently switched to culture media either with no additive or with various concentrations of $\mathrm{KCl}$. As a positive control, a portion of the cultures received NGF after the washing step.

Figure 1 shows the morphologies of PC12-C41 cells in a typical experiment of $\mathrm{NGF}$ withdrawal $/ \mathrm{K}^{+}$replacement. The neurite network from a 12-d-old culture of NGF-treated cells (Fig. $1 B$ ) began to disintegrate soon after NGF was removed from the medium and completely degenerated by $15 \mathrm{~d}$ of NGF deprivation (Fig. 1C,D). In contrast, when $44 \mathrm{~mm} \mathrm{~K}^{+}$was included in the culture medium after NGF withdrawal, a substantial portion of the neurite network was maintained (Fig. 1G,H). Elevated $\mathrm{K}^{+}$concentrations ranging from 20 to $80 \mathrm{~mm}$ were all effective in maintaining neurites under these conditions. Cells treated with elevated $\mathrm{K}^{+}$appeared to be healthy and no gross morphological deficits were observed in the cell bodies. Similar results were obtained with the parental $\mathrm{PC} 12$ cell line (data not shown), indicating that the effect of elevated $\mathrm{K}^{+}$is not limited to the PC12-C41 variant.

The same neurite-stabilizing effects of elevated $\mathrm{K}^{+}$were observed under isotonic or hypertonic conditions. Other treatments, including the permeant cAMP analog dibutyryl-cAMP $(1 \mathrm{mM})$, the phorbol ester 12-O-tetradecanoylphorbol-13-acetate (TPA; $1 \mathrm{~nm}$ to $1 \mathrm{~mm}$ ), and hypertonic $\mathrm{NaCl}(40 \mathrm{~mm})$, did not maintain neurites after withdrawal of NGF (data not shown).

Quantitative assessments of the neurite-stabilizing effect of elevated $\mathrm{K}^{+}$are illustrated in Figure 2. Cells were pretreated with NGF for $15 \mathrm{~d}$ (at this point, all cells were neurite bearing) and exposed for $13 \mathrm{~d}$ to medium containing either no additive, NGF, or $44 \mathrm{~mm} \mathrm{~K}^{+}$. The presence of neurites was scored on days 11 and 13 for each of these conditions (Fig. 2A). Less than $10 \%$ of the cells in the NGF-withdrawn cultures were neurite bearing at these times, whereas nearly all those in the $\mathrm{K}^{+}$-treated cultures maintained their neurites. The stabilizing nature of $\mathrm{K}^{+}$ on neurites is reversible, since removal of $\mathrm{K}^{+}$from the culture medium resulted in neurite degeneration (data not shown).

Figure $2 B$ shows an experiment in which cells were pretreated with NGF for various times before being switched to NGF-free medium with or without elevated $\mathrm{K}^{+}$. At all time points, the neurite-stabilizing effects of clcvated $\mathrm{K}^{+}$were rcadily apparent in comparison to the NGF-withdrawn controls. Nevertheless, there was a gradual decline of neurite-bearing cells in the $\mathrm{K}^{+}$treated cultures. Interestingly, the longer the time of NGF pretreatment, the more stable the neurites appeared to be with elevated $\mathrm{K}^{+}$. For instance, at $3 \mathrm{~d}$ of NGF pretreatment, all neurites were lost after 9 additional days with $44 \mathrm{~mm} \mathrm{~K}^{+}$, whereas after preexposure to NGF for 2-3 weeks, approximalely $80 \%$ of the cells retained neurites after 3 weeks of switching to elevated $\mathrm{K}^{+}$. In some experiments (such as that shown in Fig. $2 A$ ), elevated $\mathrm{K}^{+}$produced long-term ( $>2$ weeks) maintenance of an even higher proportion of neurites in mature cultures.

\section{Elevated $\mathrm{K}^{+}$maintains structural integrity of neurites}

The neurite networks of cultures maintained under the above conditions were examined at the electron microscopic level. The overall integrity of the ncurites maintaincd with clevated $\mathrm{K}^{+}$ appeared to be preserved, as they retained normal morphologies

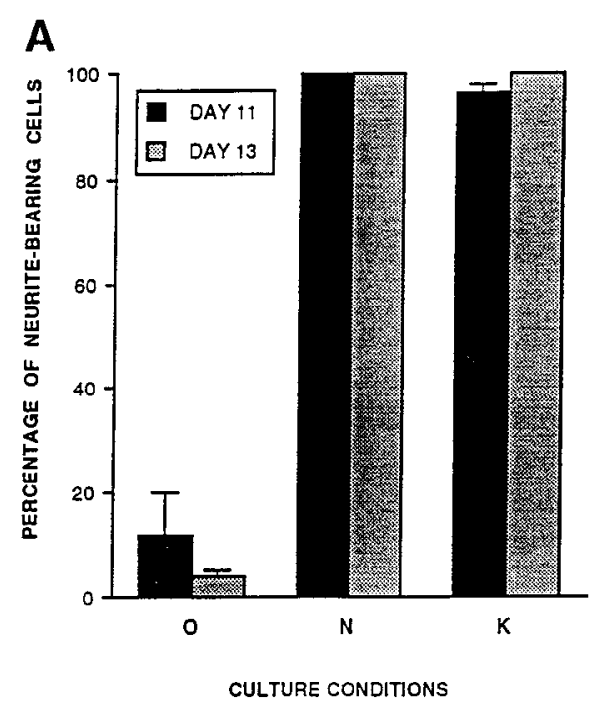

\section{B}

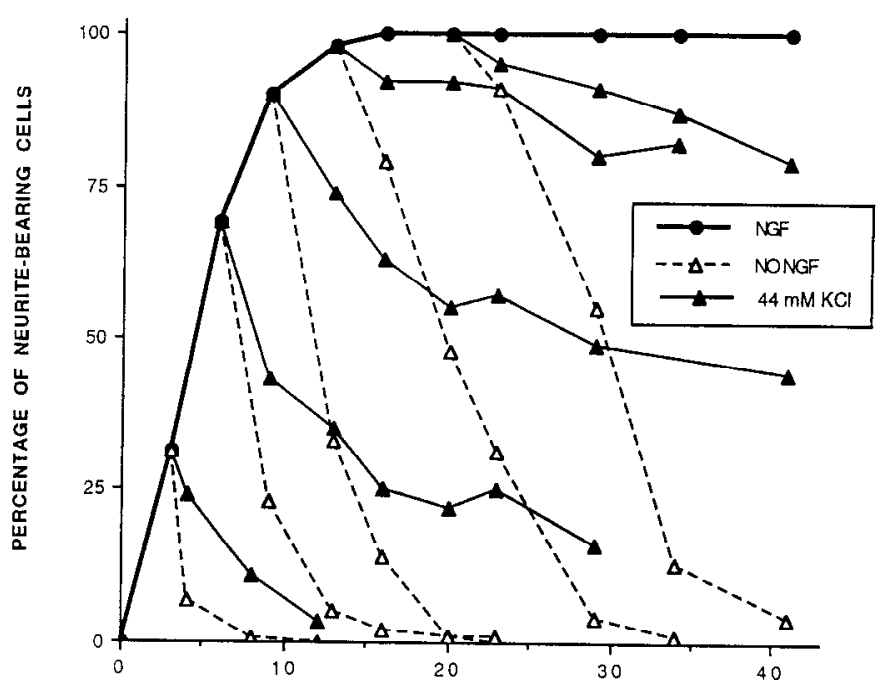

DAYS OF CULTURE

Figure 2. Quantitation of effects of elevated $\mathrm{K}^{+}$on neurites of NGFpretreated PC12-C41 cells. $A$, Cells were treated with NGF for $15 \mathrm{~d}$ and then for 11 or $13 \mathrm{~d}$ with no NGF $(O)$, the continued presence of NGF $(N)$, or $44 \mathrm{~mm} \mathrm{KCl}(K)$. At the indicated times, the proportions of neurites-bearing cells were scored as described in Materials and Methods. Vertical bars represent the range of duplicate measurements. Comparable results were obtained with five independent experiments. $B$, Sister cultures were exposed to NGF (solid circles), and at indicated times, some were washed and switched to culture media either without $\mathrm{NGF}$ (open triangles) or with $44 \mathrm{~mm} \mathrm{~K}+$ (solid triangles). Proportions of neurite-bearing cells were then determined at various times. Standard errors $(n=3)$ were omitted for clarity, but represented $<15 \%$ of the values of each point.

in terms of organelle shapes, sizes, and distributions (Fig. 3C). This was in marked contrast to the absence of identifiable structures and cytoplasmic organization in neurites found in NGFwithdrawn cultures (Fig. $3 A$ ). However, one difference was consistently noted between the NGF-treated and $\mathrm{K}^{+}$-maintained cells; there was an apparent decrease in MT density in the $\mathrm{K}^{+}$maintained neurites. Neurites from cells treated with NGF plus clevated $\mathrm{K}^{+}$(Fig. $3 D$ ) did not show this change, suggesting that elevated $\mathrm{K}^{+}$per se does not exert an effect on MT numbers. 

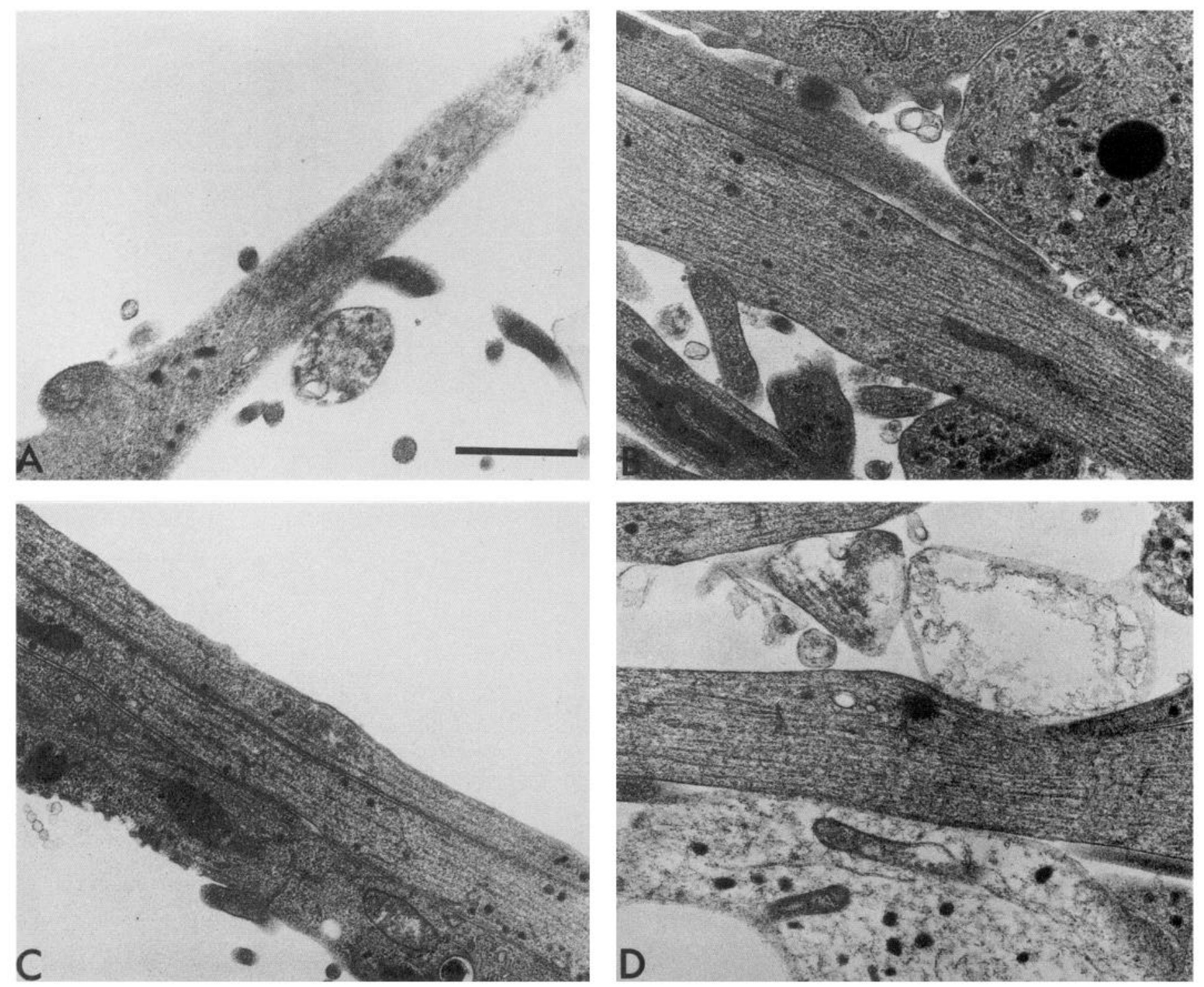

Figure 3. Electron micrographs of neurites maintained by elevated $\mathrm{K}^{+}$. Replicate cultures of PC12-C41 cells were pretreated with NGF for $15 \mathrm{~d}$, and then switched for $8 \mathrm{~d}$ to culture media with no $\mathrm{NGF}(A)$, NGF $(B), 44 \mathrm{~mm} \mathrm{~K}^{+}(C)$, or NGF plus $44 \mathrm{~mm} \mathrm{~K}^{+}(D)$. Scale bar, $1 \mu \mathrm{m}$.

\section{Neurites maintained by elevated $K^{+}$cease elongation}

As illustrated in Figure 1, the neurite networks in cultures continuously maintained with NGF appear to be more dense than in replicate cultures that were subsequently switched to elevated $\mathrm{K}^{+}$(compare Fig. $1 E, G$ ). This could in part be due to the slow loss of neurites from the $\mathrm{K}^{+}$-treated cell cultures. Additionally, neurite density could be influenced by differential actions of NGF and elevated $\mathrm{K}^{+}$on neurite growth and sprouting.

To determine if existing neurites would continue to elongate after NGF removal, we examined the average rate of neurite growth in $\mathrm{K}^{+}$and NGF-maintained cultures. In these experiments, cells were pretreated with NGF for $6-8 \mathrm{~d}$ before switching to medium containing elevated $\mathrm{K}^{+}$. This time of treatment permitted individual neurite length to be measured. Figure 4 shows that while neurites from the NGF-treated cells continued to grow (average rate $>50 \mu \mathrm{m} / \mathrm{d}$ ), those maintained by elevated $\mathrm{K}^{+}$ceased to elongate as soon as NGF was withdrawn. Note that the average length of neurites in both the control (NGF withdrawn) and the $\mathrm{K}^{+}$-maintained cultures remained relatively constant. This is in agreement with the observations that in NGF-deprived cultures of PC1 2 cells, neurites disintegrate rather than retract (Greene and Tischler, 1976). Our observations suggest that elevated $\mathrm{K}^{+}$maintains the stability of existing neurites without promoting their growth. Consistent with this is the finding that elevated $\mathrm{K}^{+}$alone has no neuritogenic effect on "naive" (not previously been exposed to NGF) PC12 (Greene et al., 1982) or PC12-C41 cells (data not shown). Also, these cells were found to extend neurites equally well in culture media containing NGF or NGF plus elevated $\mathrm{K}^{+}$, indicating that $\mathrm{K}^{+}$ per se does not inhibit neurite outgrowth.

The neurite-stabilizing effects of $\mathrm{K}^{+}$require activation of $\mathrm{Ca}^{2+}$ channels

High concentrations of $\mathrm{KCl}$ have been shown to cause membrane depolarization, which in turn activates voltage-gated ion channels. PC12 cells possess at least two types (N and L) of voltage-gated $\mathrm{Ca}^{2+}$ channels (Reber and Reuter, 1991), and we 


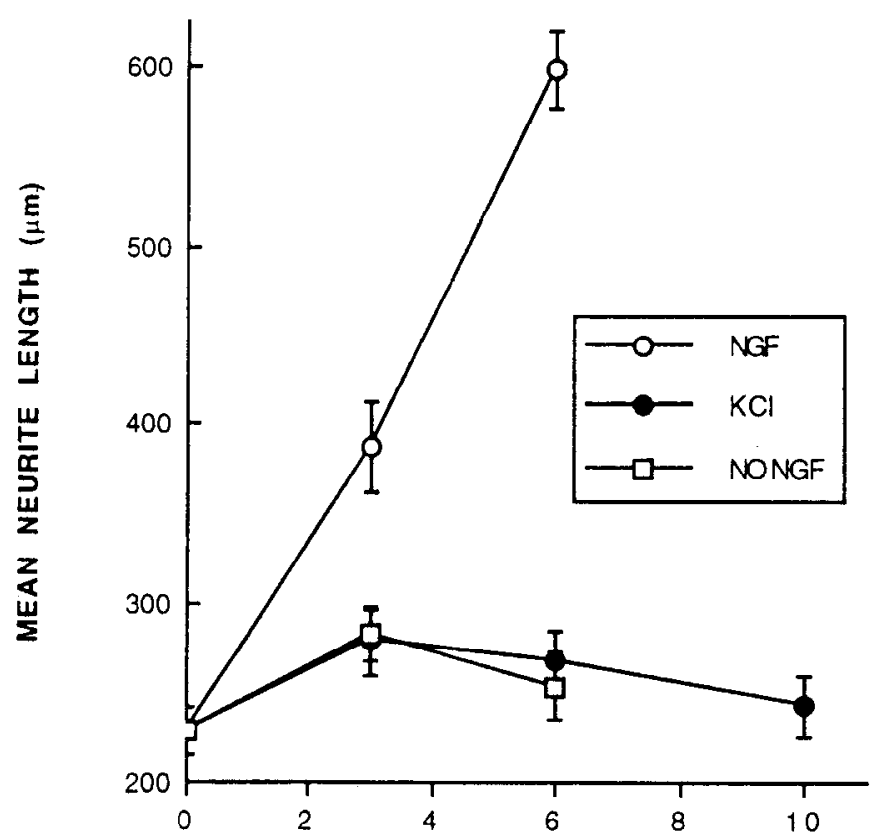

DAYS OF TREATMENT

Figure 4. Effect of elevated $\mathrm{K}^{+}$on neurite elongation by NGF-pretreated cells. Cultures of PC12-C41 cells were exposed to NGF for $6 \mathrm{~d}$ (day 0 of treatment), followed by treatment with NGF (open circles), $44 \mathrm{~mm} \mathrm{KCl}$ (solid circles), or no additive (open squares). At the indicated time points, neurite lengths were measured as described in Materials and Methods. Values represent means \pm SEM $(n=25)$. Comparable results were obtained in four additional independent experiments.

therefore sought to determine if the neurite-stabilizing effects of elevated $\mathrm{K}^{+}$are mediated via these sites. NGF-primed cells were switched to medium containing $44 \mathrm{~mm} \mathrm{~K} \mathrm{~K}^{+}$in either the absence or presence of the L-type $\mathrm{Ca}^{2+}$ channel blockers verapamil $(10 \mu \mathrm{M})$ and/or nitrendipine $(1 \mu \mathrm{M})$ and assessed $11 \mathrm{~d}$ later for the presence of neurites. As shown in Figure 5, verapamil and nitrendipine each substantially inhibited the ability of elevated $\mathrm{K}^{+}$to maintain neurites in the absence of NGF. Application of both drugs together resulted in complete blockade of $\mathrm{K}^{+}$-maintained neurite stability, suggesting that the L-type $\mathrm{Ca}^{2+}$ channel mediates this action of $\mathrm{K}^{+}$. In control experiments carried out for the same length of time, the cells exhibited normal NGF-elicited neurite outgrowth in the presence of both $\mathrm{Ca}^{2+}$ channel blockers (Fig. 5). This indicates that these inhibitors per se do not appear to produce nonspecific toxic effects on neurites.

\section{Elevated $K^{+}$maintains the primed state of $N G F$-pretreated cells}

Another effect of NGF on long-term cultures of PC12 and PC12C41 cells is its ability to "prime" the cells so that they undergo rapid NGF-dependent, transcription-independent neurite regeneration (Burstein and Greene, 1978). This "priming" phenomenon has been interpreted to indicate that NGF primes cells by inducing them to synthesize components needed for neurite growth (Burstein and Greene, 1978; Greene et al., 1982). The following experiment examined if NGF-pretreated PC12-C41 cells, deprived of NGF and treated with elevated $\mathrm{K}^{+}$, still remain primed. Replicate cultures were pretreated with NGF and then switched to culture medium either with or without NGF, or

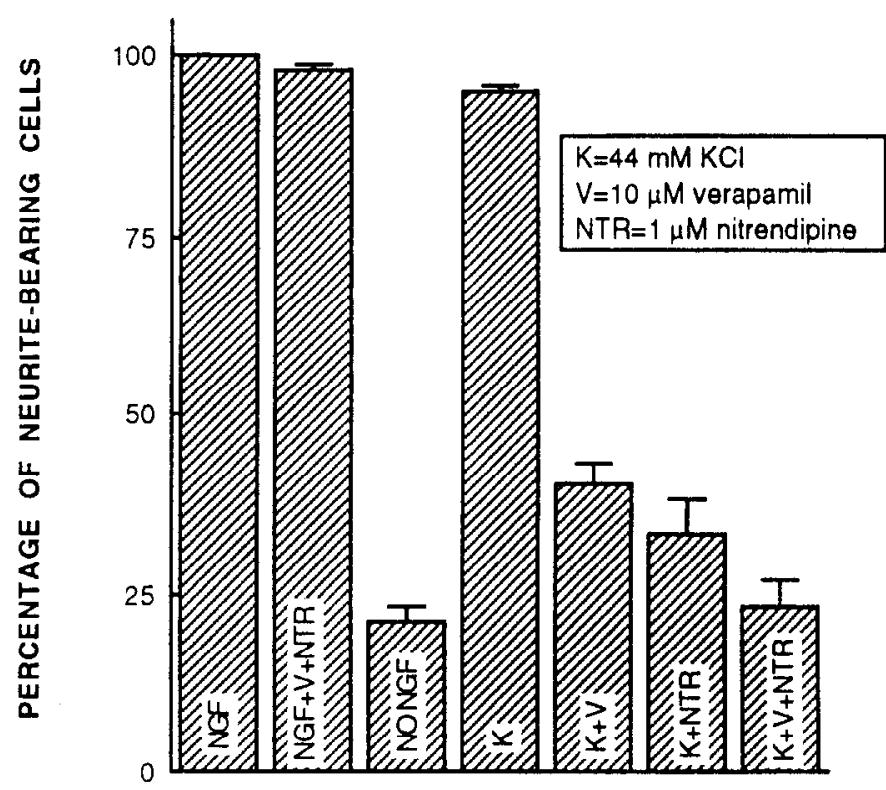

\section{CULTURE CONDITIONS (11 DAYS)}

Figure 5. Effects of $\mathrm{Ca}^{2+}$ channel blockers on neurite maintenance. Primed PC12-C41 cell cultures were washed free of NGF and treated with either NGF or $44 \mathrm{mM} \mathrm{KCl}(K)$ in the presence or absence of the $\mathrm{Ca}^{2+}$ channel blockers nitrendipine $(N T R ; 1 \mu \mathrm{M})$ and/or verapamil $(V$; $10 \mu \mathrm{M})$. Cultures from which NGF was withdrawn served as controls (no NGF). After $11 \mathrm{~d}$ of treatment, the percentage of neurite-bearing cells under each culture condition was determined. Values represent mean $\pm \operatorname{SEM}(n=3)$.

with $44 \mathrm{~mm} \mathrm{~K}^{+}$. After 10 additional days, each type of culture was divested of neurites and the cells were assayed for rapid neurite regeneration in the presence of either no additives, NGF, or $44 \mathrm{~mm} \mathrm{~K}^{+}$. The results, shown in Figure 6, demonstrate that NGF-pretreated cells maintained by elevated $\mathrm{K}^{+}$for $10 \mathrm{~d}$ still retain the ability to regenerate neurites in an NGF-dependent manner. Moreover, this regeneration was transcription independent (i.e., occurred in the presence of $10 \mu \mathrm{M}$ actinomycin D; data not shown). This indicates that elevated $\mathrm{K}^{+}$maintains NGF-pretreated cells in a primed state. In contrast, the data in Figure 6 show that NGF-primed cells subsequently switched to NGF-free culture medium no longer remain primed. Finally, this experiment shows that elevated $\mathrm{K}^{+}$treatment per se does not promote priming, does not cause NGF-primed cells to extend neurites, and lacks any neuritogenic effect under all culture conditions.

\section{Cytoskeletal proteins in NGF-pretreated cells maintained with} elevated $K^{+}$

A variety of evidence strongly indicates that various NGF-regulated cytoskeletal proteins are critical to the growth and maintenance of neurites (Aletta et al., 1990). Because elevated $\mathrm{K}^{+}$ maintains neurite stability but not growth, and maintains priming, several key cytoskeletal elements were compared under various culture paradigms.

$M T s$ and chartins. Past studies have identified cytoskeletal components, namely, $\beta$-tubulin (Black et al., 1986; Aletta and Greene, 1987), chartins (Aletta and Greene, 1987), and highmolecular-weight MAPs (Greene et al., 1983; Aletta et al., 1988b), whose states of phosphorylation dramatically increase during 
Figure 6. Effect of elevated $\mathrm{K}^{+}$on regeneration of neurites from primed PC12-C41 cells. PC12-C41 cells were primed with NGF and then treated with no NGF $(O), 44 \mathrm{~mm} \mathrm{KCl}(K)$, or NGF $(N)$ for $10 \mathrm{~d}$ prior to a regeneration as say (see Materials and Methods). The assays were carried out under the indicated conditions. After $24 \mathrm{hr}$, the cultures were scored for percentages of neurite-bearing cell clumps. At least 100 clumps were scored per condition. For each condition, the data were normalized so that $100 \%$ neurite regeneration equals the proportion of cell clumps regenerating neurites in the continuous presence of NGF. Vertical bars represent the range of duplicate measurements. Similar results were achieved in two additional experiments.

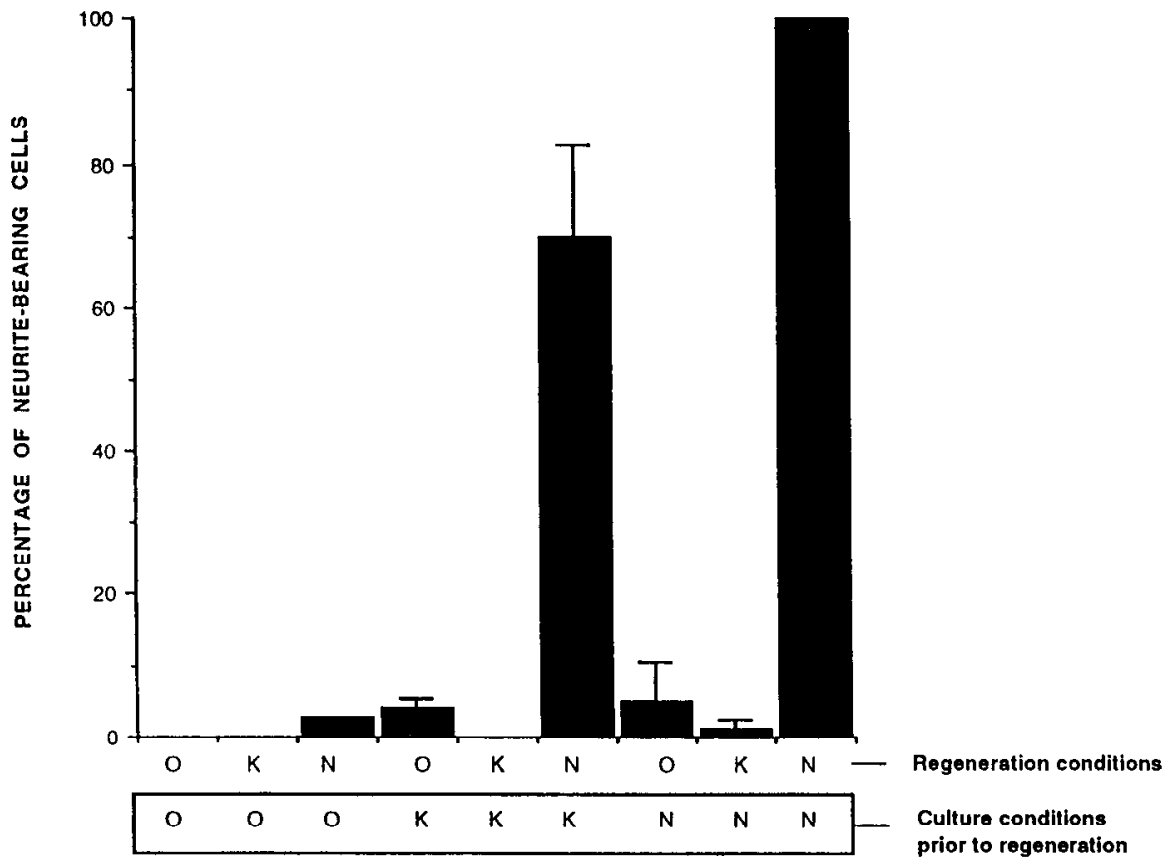

NGF-regulated neurite outgrowth. To examine their behaviors in cells maintained with elevated $\mathrm{K}^{+}$after NGF withdrawal, NGF-pretreated cultures were maintained for $9 \mathrm{~d}$ with either $\mathrm{NGF}$, no NGF, or $\mathrm{K}^{+}$-containing medium and were then metabolically labeled for $2 \mathrm{hr}$ with ${ }^{32} \mathrm{P}$-orthophosphate. An MTand MAP-enriched fraction was prepared by the differential extraction methods described by Solomon et al. (1979). Figure $7 A$ shows a representative autoradiograph of this fraction after resolution by SDS-PAGE. The $\beta$-tubulin and the chartin MAPs $(64 \mathrm{kDa}, 72 \mathrm{kDa}$, and $80 \mathrm{kDa}$ families) were identified by their apparent molecular masses, by their greatly enhanced phosphorylation after NGF treatment (compare lane 1 to lanes 2 and 3), and by their characteristic disappearance from NGFprimed cells after overnight treatment with $50 \mu \mathrm{M}$ nocodazole (Aletta and Greene, 1987; K. K. Teng, unpublished observations). The results indicate that after $9 \mathrm{~d}$ of NGF deprivation without elevated $\mathrm{K}^{+}$(lane 4 ), the levels of phosphorylated $\beta$-tu- bulin and of chartin MAPs decrease to the low levels characteristic of naive, non-NGF-treated PC12-C41 cells (lane 1). In contrast, for NGF-primed cultures subsequently treated with elevated $\mathrm{K}^{+}$for $9 \mathrm{~d}$ (lane 6 ), the levels of phosphorylation both of the $\beta$-tubulin and of the 64 and $72 \mathrm{kDa}$ chartin MAPs remain elevated (lanes 3,5). Scanning densitometry of data from eight independent experiments showed the levels of phospho- $\beta$-tubulin in NGF-deprived and $\mathrm{K}^{+}$-treated cultures to be $21 \pm 4 \%$ $(p<0.001)$ and $77 \pm 13 \%(p<0.1)$, respectively, of those in NGF-treated cultures. For the $64 \mathrm{kDa}$ chartin MAP, the corresponding levels were $53 \pm 16 \%(p<0.001)$ and $109 \pm 17 \%$ $(p>0.5)$, respectively. Although the $80 \mathrm{kDa}$ chartin MAP does not resolve adequately to permit reliable densitometric analysis, elevated $\mathrm{K}^{+}$does not appear to maintain phosphorylation of this protein. A band at apparent molecular mass $58 \mathrm{kDa}$ in the MT-enriched fraction also decreases by $30 \pm 13 \%(p<0.02)$ after the replacement of NGF with elevated $\mathrm{K}^{+}$, while no sig-

Figure 7. Effect of elevated $\mathrm{K}^{+}$on phosphorylation and levels of cytoskeletal proteins in NGF-pretreated cells. $A$, PC12-C41 cultures were labeled with ${ }^{32} \mathrm{P}$-orthophosphate for $2-3 \mathrm{hr}$ after various treatments listed below. Fractions enriched in MT and MAPs were prepared as described in Materials and Methods. Equal numbers of TCA-precipitable cpm werc analyzed by SDS-PAGE ( $5-10 \%$ acrylamide gradient gel) and the labcled phosphoproteins were visualized by autoradiography. Treatments were as follows: cells exposed to NGF for $14 \mathrm{~d}$ were either immediately labeled (lane 3) or cultured for 9 additional days either in the absence of NGF (lane 4), in the presence of NGF (lane 5), or in medium containing 44 mm $\mathrm{K}^{+}$(lane 6); naive cells (lane 1) and cells treated with NGF for $15 \mathrm{~d}$ (lane 2) are included to indicate the enhanced phosphorylation of $\beta$-tubulin and chartin MAPs. Arrows show the positions (from top to bottom) of the 72 and $64 \mathrm{kDa}$ phosphorylated chartin MAPs and phospho- $\beta$-tubulin. Arrowheads mark the positions of (from top to bottom) the $80 \mathrm{kDa}$ phosphorylated chartin MAP and the $58 \mathrm{kDa}$ bands that are NGF induced, but not preserved by elevated $\mathrm{K}^{+}$. Numbers on the right indicate the positions of molecular mass standards (given as $M_{r} \times 10^{-3}$ ). $B$, Whole-cell extracts from ${ }^{32} \mathrm{P}$-orthophosphate-labeled PC12-C41 cell cultures were subjected to SDS-PAGE. Cells primed in NGF (lane 3) for 14 d were switched to either no additives (lane 4), NGF (lane 5), or $44 \mathrm{~mm} \mathrm{~K}^{+}$(lane 6). An autoradiograph showing NGF-induced phosphorylation of MAP 1.2 in naive PC12-C41 cells (lane 1) and after $15 \mathrm{~d}$ of NGF treatment (lane 2) is included for reference. ${ }^{32} \mathrm{P}$-orthophosphate labeling for each culture condition was performed for 2-3 hr. Whole-cell lysates were prepared by direct solubilization of the cells in sample buffer and were then separated on a 5\% acrylamide gel by SDS-PAGE. The position of exogenously added bovine MAP 1 is indicated. Arrowheads indicate positions of the partially degraded MAP 1.2 phosphoproteins. Numbers on the right show the positions of molecular mass standards (given as $M_{r} \times 10^{-3}$ ). $C$, Immunoblot of MAP 1B/1.2 in whole-cell lysates of PC12-C41 cells cultured under various treatment conditions. Protein samples were harvested in sample buffer, subjected to electrophoresis on a 5-10\% acrylamide gradient gel, and electroblotted (50 mA) overnight to nitroccllulose membranc. Equal amounts of protein $(100 \mu \mathrm{g})$ were analyzed. The MAP 1B/1.2 protein was detected with monoclonal antibody $1 \mathrm{~B}-4$ (see Materials and Methods). The treatments were as follows: complete medium with no NGF (lane 1); NGF for 2 weeks (lane 2); NGF for 2 weeks and then $11 \mathrm{~d}$ with either no NGF (lane 3), NGF (lane 4), or $40 \mathrm{~mm} \mathrm{~K}^{+}$(lane 5). Lane 1 was from a different portion of the same autograph. The positions of exogenously added MAP 1 and MAP 2 are indicated on the right. 

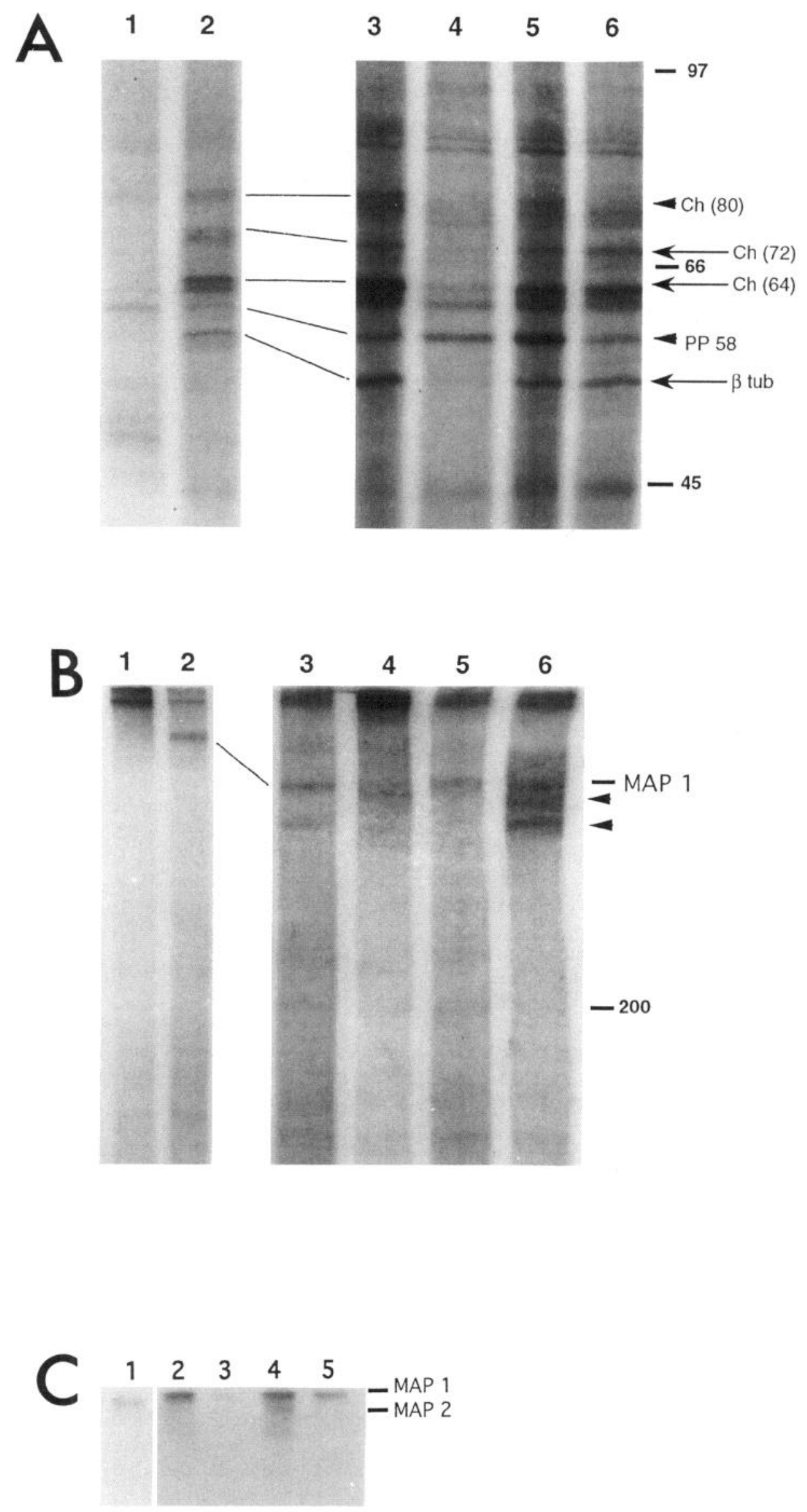


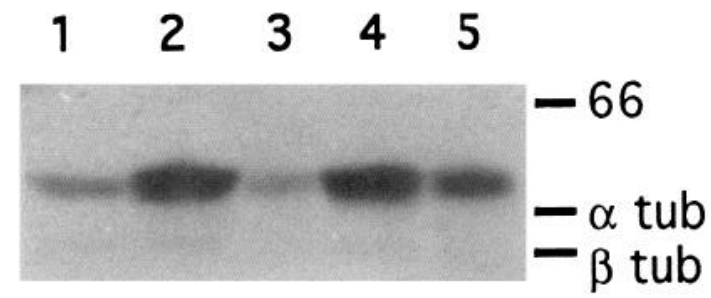

Figure 8. Effect of elevated $\mathrm{K}^{+}$on peripherin levels in NGF-pretreated PC12-C41 cells. NGF-primed PC12-C41 cells were treated and processed as described in Figure $7 C$, except that the switching was for 14 d. SDS-PAGE (5-10\% acrylamide gel) and electroblotting were performed as described in Materials and Methods. Peripherin intermediate filament protein was detected with an anti-peripherin antiserum. The treatments of cell cultures were as follows: complete medium (lane 1); NGF for 2 weeks (lane 2); pretreatment with NGF for $2 \mathrm{wk}$ followed by $14 \mathrm{~d}$ exposure to either no NGF (lane 3), NGF (lane 4), or $44 \mathrm{~mm}$ $\mathrm{K}^{+}$(lane 5). The positions of tubulin monomers ( $\alpha$ and $\beta$ tub) and the $66 \mathrm{kDa}$ molecular mass standard (given as $M_{r} \times 10^{-3}$ ) are shown on the right.

nificant difference $(p<0.5)$ was detected between the levels of this protein in the NGF-withdrawn and the $\mathrm{K}^{+}$-maintained cultures. Although $\mathrm{K}^{+}$treatment maintained enhanced phosphorylation of the 64 and $72 \mathrm{kDa}$ chartins and of $\beta$-tubulin in NGFprimed cultures, it did not induce phosphorylation of these proteins when administered alone for comparable periods to naive cultures (data not shown).

$M A P$ 1.2. The MAP 1.2 (also designated MAP 1B, Bloom et al., 1985, and MAP 5, Brugg and Matus, 1988) protein is a neuronal-specific MAP whose levels and degree of phosphorylation are NGF regulated, and are tightly correlated with neurite outgrowth in PC12 (Greene et al., 1983) and PC12-C41 cells (K. K. Teng and L. A. Greene, unpublished observations). Figure $7 B$ shows an autoradiograph of whole-cell extracts of ${ }^{32} \mathrm{P}$ orthophosphate-labeled cultures. Prior to labeling, the cultures were either continuously maintained with NGF for $21 \mathrm{~d}$, or pretreated with NGF for $14 \mathrm{~d}$ and then maintained for an additional $7 \mathrm{~d}$ either without $\mathrm{NGF}$ or with elevated $\mathrm{K}^{+}$. As shown in Figure $7 B$, phosphorylated MAP 1.2 migrates at a characteristic position and shows a marked increase in level in response to long-term NGF treatment (compare lanes 1,2). Whereas NGF withdrawal (lane 4) leads to a decrease in MAP 1.2 phosphorylation, significant levels of MAP 1.2 phosphorylation remain in primed cells subsequently treated with elevated $\mathrm{K}^{+}$(lane 6). However, there consistently occurs an apparent partial degradation of this phosphoprotein in the $\mathrm{K}^{+}$-treated cells as suggested by the presence of several extra bands below the main phosphorylated MAP 1.2 band (compare lanes 5, 6). Scanning densitometry of a large number of independent experiments $(n$ $=8$ ) revealed that the levels of total phospho-MAP 1.2 in NGFdeprived and $\mathrm{K}^{+}$-treated cultures were $36 \pm 12 \%$ and $119 \pm$ $26 \%$, respectively, of those in cultures maintained with NGF. Note that the relative phosphorylation levels of MAP 1.2 in the elevated $\mathrm{K}^{+}-$maintained culture represented the sum total of nondegraded and partially degraded MAP 1.2 proteins. Since NGF-pretreated cells switched to medium with NGF plus elevated $\mathrm{K}^{+}$do not show partial MAP 1.2 degradation (data not shown), it is unlikely that elevated $\mathrm{K}^{+}$treatment itself directly leads to this effect.

We also examined the levels of MAP 1.2 protein in the above cultures by immunoblotting whole-cell extracts with an appropriate antibody (1B-4; Bloom et al., 1985). Recognition of MAP

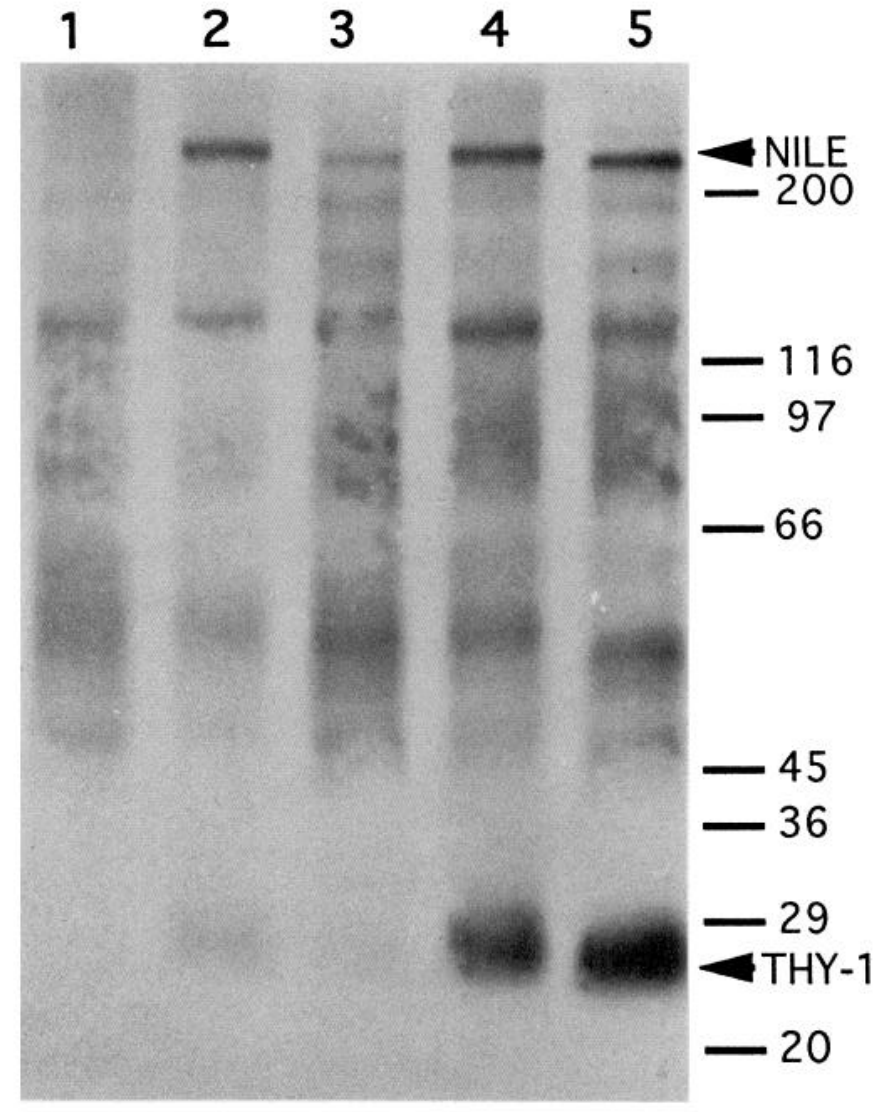

Figure 9. Effects of elevated $\mathrm{K}^{+}$on ${ }^{3} \mathrm{H}$-fucose-labeled proteins in NGFpretreated PC12-C41 cultures. PC12-C41 cultures were maintained as follows: no NGF (lane 1); NGF for $15 \mathrm{~d}$ (lane 2); or NGF pretreatment for $15 \mathrm{~d}$ followed by $12 \mathrm{~d}$ with either no NGF (lane 3), NGF (lane 4), or $44 \mathrm{~mm} \mathrm{KCl} \mathrm{(lane} \mathrm{5).} \mathrm{Cultures} \mathrm{were} \mathrm{labeled} \mathrm{for} \mathrm{the} \mathrm{last} 3 \mathrm{~d}$ with ${ }^{3} \mathrm{H}$ fucose as described in Materials and Methods and whole-cell lysates were analyzed by SDS-PAGE (6-12\% acrylamide gradient gel). Equal numbers of TCA-precipitable counts were loaded per lane. Numbers on the right indicate the positions of molecular mass standards (given as $M, \times 10^{-3}$ ). Arrowheads mark the positions of (from top to bottom) NILE/L1 and Thy-1 glycoproteins. Comparable results were obtained in three independent experiments.

1.2 by this antibody is not affected by the state of MAP 1.2 phosphorylation (Aletta et al., 1988b; Teng, unpublished observations). The experiment (Fig. $7 C ; n=7$ ) showed that in NGF withdrawn cultures (lane 3), the MAP 1.2 protein decreased to levels $(24 \pm 7 \%)$ comparable to those in naive cells (lane 1). In contrast, replacement with elevated $\mathrm{K}^{+}$(lane 5) maintained the MAP 1.2 protein, although at somewhat reduced levels $(88 \pm 21 \%)$ when compared to those in NGF-treated cultures (lanes 2, 4). In some experiments, there was a slight but reproducible shift in the relative mobility of the MAP 1.2 protein in the $\mathrm{K}^{+}$-treated cell samples, consistent with partial degradation and/or changes in phosphorylation state. Finally, exposure to elevated $\mathrm{K}^{+}$alone without NGF pretreatment did not affect the levels of MAP 1.2 protein or phosphorylation (data not shown).

Peripherin intermediate filament protein. We next examined the protein level of the intermediate filament protein peripherin. This is by far the most abundant intermediate filament in $\mathrm{PC} 12$ cells and is upregulated by NGF (Leonard et al., 1988; Aletta et al., 1989). Figure 8 shows the results of an immunoblot with specific antiserum against peripherin (Aletta et al., 1988a) for 
cells cultured under various conditions. By $12 \mathrm{~d}$ of NGF deprivation (lane 3 ), the amount of peripherin decreased by $45 \pm$ $9 \%$ to the basal level in naive cells (lane 1). However, primed cells (lane 2 ) switched to elevated $\mathrm{K}^{+}$(lane 5) consistently $(n=$ 4) expressed high levels of peripherin, albeit slightly lower in relative abundance $(78 \pm 12 \%)$ than in cultures maintained with NGF (lanes 2,4). Application of elevated $\mathrm{K}^{+}$alone to naive cultures had no apparent effect on peripherin levels (data not shown).

\section{Elevated $K^{+}$maintains the levels of NILE/L1 glycoprotein}

In addition to cytoskeletal proteins, NGF also selectively enhances expression of several surface glycoproteins that may play roles in neurite outgrowth (McGuire et al., 1978). These include the Thy-1 (Richter-Landsberg et al., 1985) and NILE/Ll glycoproteins (McGuire et al., 1978; Bock et al., 1985; Sajovic et al., 1986). Previous work has established that in naive $\mathrm{PC} 12$ (Doherty et al., 1988) and PC12-C41 (Teng and Greene, unpublished observations) cultures, membrane depolarization alone increases the level of Thy-1 protein, but not that of NILE/L1. We therefore examined the levels of these and other glycoproteins in the $\mathrm{K}^{+}$-maintained cultures. NGF-primed cultures were switched either to NGF-free medium or to medium containing $44 \mathrm{~mm} \mathrm{KCl}$ for $15 \mathrm{~d}$ and labeled with ${ }^{3} \mathrm{H}$-fucose during the last $3 \mathrm{~d}$ of culture. Whole-cell extracts were analyzed by SDS-PAGE and fluorography. Figure 9 shows, as previously demonstrated, that NGF selectively increases the labeling of the NILE/L1 and Thy-1 glycoproteins. Withdrawal of NGF (lane 3) resulted in a marked decrease in labeling of both glycoproteins. In contrast, in NGF-pretreated cells that were subsequently switched to elevated K+ (lane 5), the level of NILE/L.1 glycoprotein labeling was maintained at levels comparable to those in cultures continuously treated with NGF (lanes 2,4 ). The increase of Thy-1 labeling in cells treated with elevated $\mathrm{K}^{+}$is consistent with previous work.

\section{Discussion}

The purpose of this study was to investigate the effect of membrane depolarization on neurite stabilization. Past work has established that elevated $\mathrm{K}^{+}$exerts survival-promoting effects on certain neurons (Nishi and Berg, 1981; Achenson et al., 1987; Wakade et al., 1988). In these studies, the surviving cells also possessed neurites. For example, Koike et al. (1989) showed that elevated $\mathrm{K}^{+}$prevents the death of rat sympathetic neurons after NGF deprivation and that the neurites of such cells remain intact. The question is thus raised as to whether the presence of neurites in cultures treated with elevated $\mathrm{K}^{+}$is simply an indirect consequence of neuronal survival or is a direct and independent effect of membrane depolarization. In contrast to primary neurons, the model systems that we employed, namely, the $\mathrm{PC1}$ - $\mathrm{C} 41$ and $\mathrm{PC} 12$ cell lines, do not require the continuous presence of NGF or elevated $\mathrm{K}^{+}$for survival in serum-containing medium (Rukenstein et al., 1991). This permitted us to isolate the effects of elevated $\mathrm{K}^{+}$on survival from its potential actions on neurites. Our data provide evidence that elevated $\mathrm{K}^{+}$can maintain preexisting neurites as well as NGF-promoted priming, but does not itself cause priming or neurite growth.

The ability of elevated $\mathrm{K}^{+}$to prevent neurite disintegration in our cultures appeared to depend in part on the duration of NGF pretreatment. We also observed that neurite networks in cultures maintained by elevated $\mathrm{K}^{+}$were consistently less dense than those treated with NGF (compare Fig. $1 B, G$ ). These ob- servations suggest the existence of two neurite populations in the NGF-treated cultures: one that is less well-maintained by elevated $\mathrm{K}^{+}$, and another that is more effectively stabilized by this treatment. One possibility for the biphasic efficacy is that more mature and better established neurites show greater stability in elevated $\mathrm{K}^{+}$.

Although preexisting neurites are maintained by elevated $\mathrm{K}^{+}$, neurite elongation ceases after the removal of NGF from the culture medium. Few, if any, growth cone-like structures were found at the ends of the neurite shafts maintained by elevated $\mathrm{K}^{+}$. Since neurite outgrowth is normal when cells are exposed to both $\mathrm{NGF}$ and elevated $\mathrm{K}^{+}$, it seems unlikely that cessation of neurite elongation in cultures maintained by elevated $\mathrm{K}$ ' alone is due to an inhibitory effect induced by chronic membrane depolarization. Rather, removal of NGF is the more plausible cause of this effect. Past studies have demonstrated that NGF locally regulates the form, motility, and locomotion of growth cones (Seeley and Greene, 1983; Connolly et al., 1987; Aletta and Greene, 1988) and that these actions are required for neurite extension (Aletta and Greene, 1988). Membrane depolarization is unable to mimic these effects (Seeley and Greene, 1983) and this is likely to account, at least in part, for the absence of neurite elongation observed in our experiments. Thus, replacement of $\mathrm{NGF}$ with elevated $\mathrm{K}^{+}$in these cells operationally dissects away the elongation aspect of neuritogenesis from those mechanisms underlying neurite stabilization.

While the precise mechanism whereby elevated $\mathrm{K}^{+}$maintains the neurite network in the absence of NGF remains to be determined, our data indicate that $\mathrm{Ca}^{2+}$ entry through voltagesensitive $\mathrm{L}$-type $\mathrm{Ca}^{2+}$ channels is responsible for initiating this phenomenon. This also suggests that even under chronic depolarizing conditions, $\mathrm{PCl} 2$ cell L-type $\mathrm{Ca}^{2+}$ channels do not become totally desensitized. Furthermore, our results show that the continuous presence of elevated $\mathrm{K}^{+}$is necessary for maintaining the neurite network; withdrawal of elevated $\mathrm{K}^{+}$resulted in neurite disintegration, and pulses of $\mathrm{KCl}$ treatment fail to stabilize neurites in NGF-deprived cultures (Teng, unpublished observations).

\section{Effects of elevated $K^{+}$on cytoskeletal proteins}

Previous work has shown that the NGF-promoted neuritogenesis requires transcription and that "priming" appears to be due to the accumulation of specific gene products (Burstein and Greene, 1978; Greene et al., 1982). Related studies have established that NGF causes increased synthesis as well as enhanced phosphorylation of a variety of cytoskeletal proteins (reviewed by Aletta et al., 1990). These alterations in the cytoskeleton have been either causally linked to, or correlated with, the formation and stabilization of neurites as well as the acquisition of priming (Greene, 1984; Aletta et al., 1990). It is therefore notable that elevated $\mathrm{K}^{+}$substantially maintains many of the currently known NGF-induced changes in cytoskeletal proteins. These include, as shown here, phospho- $\beta$-tubulin, phosphorylated chartins, MAP 1.2, and peripherin as well as high- and low-molecularweight tau proteins (Teng, unpublished observations). Although our experiments do not distinguish between cause and effect in this regard, it is tempting to consider that the preservation of cytoskeletal protein changes is responsible for the capacity of elevated $\mathrm{K}^{+}$to stabilize neurites and to maintain the primed state.

Of the cytoskeletal proteins examined in $\mathrm{K}^{+}$-treated cultures, only the levels of the phosphorylated $80 \mathrm{kDa}$ chartins and of 
an unidentified $58 \mathrm{kDa}$ phosphoprotein were specifically reduced to those in NGF-deprived cells. These proteins therefore do not appear to play a required role in neurite stabilization. However, our findings do not rule out the possibility that such proteins may be associated with neurite elongation.

Ultrastructural examination of neurites maintained with elevated $\mathrm{K}^{+}$revealed an apparent decrease in $\mathrm{MT}$ abundance. Consistent with this is that although $44 \mathrm{mM} \mathrm{K}^{+}$maintained $\beta$-tubulin and several MAPs at elevated levels of abundance and/or phosphorylation, these levels were somewhat below those in cultures treated continuously with NGF. We do not currently know whether the MTs maintained with elevated $\mathrm{K}^{+}$treatment represent a specific subpopulation of particularly stable MTs or whether the loss of MT is random.

\section{Elevated $K^{+}$and priming}

"Priming" has been operationally defined as the transcriptiondependent acquisition of the capacity of cells to undergo rapid NGF-induced, transcription-independent neurite outgrowth and regeneration (Burstein and Greene, 1978; Greene et al., 1982; Greene, 1984). Three aspects of priming were considered here: induction of priming, stimulation of rapid neurite regeneration by NGF-primed cells, and maintenance of priming. Induction of the primed state requires transcription (Burstein and Greene, 1978), and on this basis, it has been hypothesized that priming reflects the accumulation of gene products needed for neurite formation and stabilization. The observation that elevated $\mathrm{K}^{+}$ does not cause priming indicates that it does not directly induce genes required for neurite outgrowth (Greene et al., 1982). This is consistent with differences in the capacities of NGF and $\mathrm{K}^{+}$ to affect the levels of at least several cytoskeletal and cell surface proteins in naive cells. Stimulation of neurite regeneration by primed cells does not require transcription, but does require the presence of agents like NGF. Our data indicate that elevated $\mathrm{K}^{+}$ lacks the capacity to mimic this nontranscriptional NGF action. This could, at least in part, reflect the inability of elevated $\mathrm{K}^{+}$ to promote neurite elongation (Fig. 4). In contrast to the lack of effect of depolarization on acquisition of priming or on neurite regeneration, we found that elevated $\mathrm{K}^{+}$preserves priming of NGF-pretreated cells (Fig. 6). Maintenance of the primed state should depend in part on the retention or continued accumulation of gene products needed for neurite outgrowth. The elevated levels of several cytoskeletal proteins and cell surface adhesion molecules that we observed in $\mathrm{K}^{+}$-maintained cells are consistent with this possibility and raise the prospect that such proteins play a causal role in priming. Such effects may be accomplished by different means including maintaining the enhanced transcription of NGF-activated genes, stabilizing the levels of messages previously enhanced by NGF, or stabilizing proteins whose intracellular levels increase with NGF treatment. Since priming may also include long-term posttranslational modification of various cellular proteins (such as phosphorylation of MAPs), our data suggest that elevated $\mathrm{K}^{+}$may also either maintain or mimic this action of NGF.

\section{Biological implications}

It has been well documented that elevated $\mathrm{K}^{+}$can mimic certain aspects of trophic factor actions such as promoting neuronal survival and maturation. Our findings established that, in addition, depolarization can stabilize preexisting neurites. It will therefore be appropriate in future experiments to consider which of these actions is being examined. For example, Riederer et al.
(1992) recently reported that depletion of the glial population in rat telencephalon cell cultures results in a dramatic reduction of many neuronal-specific cytoskeletal proteins and that exposure of such neuronally enriched cultures to elevated $\mathrm{K}^{+}$largely prevents the loss of these proteins. It was therefore proposed that elevated $\mathrm{K}^{+}$promotes differentiation of telencephalic neurons as it does for cultured chick dorsal root ganglionic neuron precursors (Chalazonitis and Fischbach, 1980). An equally plausible alternative raised by the present findings is that elevated $\mathrm{K}^{+}$prevents the "dedifferentiation" of telencephalic neurons caused by the withdrawal of trophic support supplicd by glia.

Our experiments implicate $\mathrm{Ca}^{2+}$ influx as a key mediator of depolarization-promoted neurite maintenance. An intriguing implication of this is that conditions that elevate intraneuronal $\mathrm{Ca}^{2+}$ may lead to stabilization of preexisting axons or dendrites in the intact nervous system. The phenomena described here thus provide a mechanism whereby enhanced electrical excitation or activation of receptors gating $\mathrm{Ca}^{2+}$ could provide selective preservation of specific synaptic connections. Such actions might be particularly important under circumstances in which the supply of neurotrophic factors is absent or limiting, as may well be the case in the adult nervous system.

In summary, we have described an experimental system in which it is possible to evaluate separately the effects of depolarization on neuronal survival, differentiation, and maintenance of phenotype. We show that elevated $\mathrm{K}^{+}$, via $\mathrm{Ca}^{2+}$ influx, preserves precxisting ncuritcs and "priming" after withdrawal of a neurotrophic factor and appears to do so, at least in part, by selectively maintaining specific NGF-induced cellular responses.

\section{References}

Achenson A, Barde Y-A, Thoenen H (1987) High K+-mediated survival of spinal sensory neurons depends on developmental stage. Exp Cell Res 170:56-63.

Aletta JM, Greene LA (1987) Sequential phosphorylation of chartin microtubule-associated proteins is regulated by the presence of $\mathrm{mi}$ crotubules. J Cell Biol 105:277-290.

Aletta JM, Greene LA (1988) Growth cone configuration and advance: a time-lapse study using video-enhanced differential interference contrast microscopy. J Neurosci 8:1425-1435.

Aletta JM, Angeletti R, Liem RKH, Purcell C, Shelanski ML, Greene LA (1988a) Relationship between the nerve growth factor-regulated clone 73 gene product and the 58-kilodalton neuronal intermediate filament protein (peripherin). J Neurochem 51:1317-1320.

Aletta JM, Lewis SA, Cowan NJ, Greene LA (1988b) Nerve growth factor regulates both the phosphorylation and steady-state levels of microtubule-associated protein 1.2 (MAP 1.2). J Cell Biol 106:15731581.

Aletta JM, Shelanski ML, Greene LA (1989) Phosphorylation of the peripherin 58-kDa neuronal intermediate filament protein: regulation by nerve growth factor and other agents. J Biol Chem 264:4619-4627.

Aletta JM, Tsao H, Greene LA (1990) How do neurites grow? Clues from NGF-regulated cytoskeletal phosphoproteins. In: Trophic factors and the nervous system (Horrocks LA, ed), pp 203-218. New York: Raven.

Batistatou A, Greene LA (1991) Aurintricarboxylic acid rescues PC12 cells and sympathetic neurons from cell death caused by nerve growth factor deprivation: correlation with suppression of endonuclease activity. J Cell Biol 115:461-471.

Black MM, Aletta JM, Greene LA (1986) Regulation of microtubule composition and stability during nerve growth factor-promoted neurite outgrowth. J Cell Biol 103:545-557.

Bloom GS, Luca FC, Vallee RB (1985) Microtubule-associated protein 1B: identification of a major component of the neuronal cytoskeletal. Proc Natl Acad Sci USA 82:5404-5408.

Bock E, Richter-Landsberg C, Faissner A, Schachner M (1985) Demonstration of immunochemical identity between the NGF-inducible 
large external (NILE) glycoprotein and the cell adhesion molecule L1. EMBO J 4:2765-2768.

Bradford MM (1976) A rapid and sensitive method for the quantitation of microgram quantities of protein utilizing the principle of protein-dye binding. Anal Biochem 72:248-252.

Brugg B, Matus A (1988) PC12 cells express juvenile microtubuleassociated proteins during nerve growth factor-induced neurite outgrowth. J Cell Biol 107:643-650.

Burstein DE, Greene LA (1978) Evidence for RNA synthesis-dependent and -independent pathways in stimulation of neurite outgrowth by nerve growth factor. Proc Natl Acad Sci USA 75:6059-6063.

Chalazonitis A, Fischbach GD (1980) Elevated potassium induces morphological differentiation of dorsal root ganglionic neurons in dissociated cell culture. Dev Biol 78:141-151.

Chamberlain JP (1979) Fluorographic detection of radioactivity in polyacrylamide gels with the water-soluble fluor, sodium salicylate. Anal Biochem 98:132-135.

Connolly JL, Seeley PJ, Greene IAA (1987) Rapid regulation of neuronal growth cone shape and surface morphology by nerve growth factor. Neurochem Res 12:861-868.

Doherty P, Mann DA, Walsh FS (1988) Comparison of the effects of NGF, activators of protein kinase $\mathrm{C}$, and a calcium ionophore on the expression of Thy-1 and N-CAM in PC1 2 cell cultures. J Cell Biol 107:333-340.

Goldberg DJ, Burmeister DW (1986) Stages in axon formation: observations of growth of Aplysia axons in culture using video-enhanced contrast-differential interference microscopy. J Cell Biol 103:19211931.

Greene LA (1984) The importance of both early and delayed responses in the biological actions of nerve growth factor. Trends Neurosci 7:9194.

Greene LA, Tischler AS (1976) Establishment of a noradrenergic clonal line of rat adrenal pheochromocytoma cells which respond to nerve growth factor. Proc Natl Acad Sci USA 73:2424-2428.

Grcenc LA, Tischler AS (1982) PC12 pheochromocytoma cultures in neurobiological research. Adv Cell Neurobiol 3:373-414.

Greene LA, Burstein DE, Black MM (1982) The role of transcriptiondependent priming in nerve growth factor promoled neurite outgrowth. Dev Biol 91:305-316.

Greene LA, Liem RKH, Shelanski ML (1983) Regulation of a high molecular weight microtubule-associated protein in $\mathrm{PC} 12$ cells by nerve growth factor. J Cell Biol 103:76-83.

Greene LA, Aletta JM, Rukenstein A, Green SH (1987) PC12 pheochromocytoma cells: culture, nerve growth factor treatment, and experimental exploitation. Methods Enzymol [B] 147:207-216.

Greene LA, Volonté C, Chalazonitis A (1990) Purine analogues inhibit nerve growth factor-promoted neurite outgrowth by sympathetic and sensory neurons. J Neurosci 10:1479-1485.

Grcenc LA, Sobcih MM, Teng KK (1991) Methodologies for the culture and experimental use of the $\mathrm{PC} 12$ rat pheochromocytoma cell line. In: Culturing nerve cells (Banker G, Goslin K, eds), pp 207-226. Cambridge, MA: MIT Press.

Halegoua S (1987) Changes in the phosphorylation and distribution of vinculin during nerve growth factor induced neurite outgrowth. Dev Biol 121:97-104.

Koike T, Martin DP, Johnson EM Jr (1989) Role of $\mathrm{Ca}^{+2}$ channels in the ability of membrane depolarization to prevent neuronal death induced by trophic-factor deprivation: evidence that levels of internal $\mathrm{Ca}^{+2}$ determine nerve growth factor dependence of sympathetic ganglion cells. Proc Natl Acad Sci USA 86:6421-6425.

Laemmli UK (1970) Cleavage of structural protein during the assembly of the head of bacteriophage T4. Nature 227:680-685.
Leonard DGB, Gorham JD, Cole P, Greene LA, Ziff EB (1988) A nerve growth factor-regulated messenger RNA encodes a new intermediate filament protein. J Cell Biol 106:181-193.

Levi A, Alemá S (1991) The mechanism of action of nerve growth factor. Annu Rev Pharmacol Toxicol 31:205-228.

Levi-Montalcini R, Angeletti PU (1968) Nerve growth factor. Physiol Rev 48:534-569.

Lewis SA, Sherline P, Cowan NJ (1986) A cloned cDNA encoding MAP1 detects a single copy gene in mouse and a brain-abundant mRNA whose level decreases during development. J Cell Biol 102: 2106-2114.

McGuire JC, Greene LA, Furano AV (1978) NGF stimulates incorporation of fucose or glucosamine into an external glycoprotein in cultured rat PC12 pheochromocytoma cells. Cell 15:357-365.

Mobley WC, Schenker A, Shooter EM (1976) Characterization and isolation of proteolytically modified nerve growth factor. Biochemistry 15:5543-5552.

Nishi R, Berg DK (1981) Effects of high $\mathrm{K}^{+}$concentrations on the growth and development of ciliary ganglion neurons in cell culture. Dev Biol 87:301-307.

Prentice HM, Moore SE, Dickson JG, Doherty P, Walsh FS (1987) Nerve growth factor-induced changes in neural cell adhesion molecule (N-CAM) in PC12 cells. EMBO J 6:1859-1863.

Reber BFX, Reuter H (1991) Dependence of cytosolic calcium in differentiating rat pheochromocytoma cells on calcium channels and intracellular stores. J Physiol (Lond) 435:145-162.

Richter-Landsberg C, Greene LA, Shelanski ML (1985) Cell surface Thy-1-cross-reactive glycoprotein in cultured PC1 2 cells: modulation by nerve growth factor and association with the cytoskeleton. J Neurosci $5: 468-476$.

Riederer BM, Monnet-Tschudi F, Honegger P (1992) Development and maintenance of the neuronal cytoskeleton in aggregated cell cultures of fetal rat telencephalon and influence of elevated $\mathrm{K}^{+}$concentrations. J Neurochem 58:649-658.

Rukenstein A, Rydel RE, Greene LA (1991) Multiple agents rescuc PCI 2 cells from serum-free cell death by translation- and transcription-independent mechanisms. J Neurosci 11:2552-2563.

Sajovic P, Kouvelas E, Trenkner E (1986) Probable identity of NILE glycoprotein and the high-molecular-weight component of $L 1$ antigen. J Neurochem 47:541-546.

Salton SRJ, Shelanski ML, Greene LA (1983) Biochemical properties of the nerve growth factor-inducible large external (NILE) glycoprotein. J Neurosci 3:2420-2430.

Seeley PJ, Greene LA (1983) Short latency local actions of nerve growth factor at the growth cone. Proc Natl Acad Sci USA 80:27892793 .

Solomon F, Magendantz M, Salzman A (1979) Identification with cellular microtubules of one of the co-assembly microtubule-associatcd protcins. Cell 18:431-438.

Teng KK, Greene LA (1991) Elevated potassium maintains neurite stability in a PC12 mutant cell line after NGF withdrawal. Soc Neurosci Abstr 17:598.8.

Towbin H, Staehlin T, Gordon J (1979) Electrophoretic transfer of proteins from polyacrylamide gels to nitrocellulose sheets: procedure and some applications. Proc Natl Acad Sci USA 76:4350-4354.

Troy CM, Greene LA, Shelanski ML (1992) Neurite outgrowth in peripherin-depleted PC12 cells. J Cell Biol 117:1085-1092.

Wakade AR, Wakade TD, Malhotra RK, Bhave SV (1988) Excess K+ and phorbol ester activate protein kinase $\mathrm{C}$ and support the survival of chick sympathetic neurons in culture. J Neurochem 51:975-983. 